Gut, 1977, 18, 266-273

\title{
Ischaemic strictures of the small intestine in Nigeria
}

\author{
S. G. SUBBUSWAMY,1 AND F. I. IWEZE \\ From the Departments of Pathology and Surgery, University of Benin, Benin City, Nigeria
}

SUMMARY Eleven specimens of small intestinal strictures were seen at the Pathology Department of the University of Benin Teaching Hospital, Benin City, Nigeria, during a period of two and a half years. Eight of them were ischaemic in origin and the clinical and pathological features of these eight cases are described. In five of the cases, the ischaemia could be related to inguinal hernia, with herniorrhaphy a few weeks before surgery for stricture in four cases. The most important factor in making a clinical or pathological diagnosis of ischaemic stricture of the small intestine appears to be awareness of the condition. The importance is emphasised of studying the mesentery, with particular attention to lymph nodes and blood vessels, before making a final diagnosis on intestinal lesions.

Tuberculosis, Crohn's disease, and neoplasia are generally accepted as the major causes of acquired strictures of the intestines. Strictures of small and large intestines resulting from prolonged ischaemia or occlusion of small blood vessels are well documented. It is our experience, however, that the diagnosis of this condition is often missed because the clinical and pathological features are not sufficiently well recognised.

While reviewing material seen at the Pathology Department, University of Benin Teaching Hospital, we were struck by the finding that ischaemic strictures of the small intestine were not uncommon in the Bendel (old Midwestern) state of Nigeria. Eight of 11 specimens of strictures of the small intestine or terminal ileum and caecum seen in this Department between January 1973 and July 1975 were ischaemic in origin. This paper deals with the

'Present address: Department of Pathology, A. B. U. Hospital, Zaria, Nigeria.

Received for publication 8 October 1976 clinical and pathological features of these eight cases.

\section{Methods}

The material consisted of eight specimens of intestines removed surgically at the University of Benin Teaching Hospital. Sections were taken from representative areas of the intestines and the mesentery (including blood vessels and lymph nodes) and embedded in paraffin, and sectioned.

The sections were stained with haematoxylin and eosin. Selected specimens were stained by Perl's technique for iron and Verhoeff-van Gieson technique for elastic fibres.

\section{CLINICAL FEATURES}

The salient clinical features of the eight cases are summarised in Table 1.

The prominent symptoms were post-prandial abdominal pain, loss of weight, and alteration of bowel habits.

Table 1 Clinical features in eight cases of ischaemic stricture of small intestine

\begin{tabular}{|c|c|c|c|c|c|c|c|c|c|}
\hline $\begin{array}{l}\text { Case } \\
\text { no. }\end{array}$ & Sex & $\begin{array}{l}\text { Age } \\
(y r)\end{array}$ & $\begin{array}{l}\text { Duration of } \\
\text { symptoms }(y r)\end{array}$ & Abdominal pain & Bowel habits & Melaenu & Vomiting & $\begin{array}{c}\text { Loss of } \\
\text { weight }\end{array}$ & $\begin{array}{l}\text { History of } \\
\text { previous } \\
\text { herniorrhaphy } \\
(\mathrm{mth})\end{array}$ \\
\hline 1 & $\mathbf{M}$ & 55 & 3 & - & - & - & - & - & - \\
\hline 2 & $\mathbf{M}$ & 15 & $1 \mathrm{mth}$ & Central & Constipation & - & + & + & 1 \\
\hline 3 & $\mathbf{M}$ & 58 & $2 \mathrm{mth}$ & $\mathbf{R}$ iliac fossa & Constipation & + & - & + & 2 \\
\hline 4 & $\mathbf{M}$ & 48 & 4 & Central & $\begin{array}{l}\text { Constipation } \\
\text { Diarrhoea }\end{array}$ & - & + & + & 3 \\
\hline 5 & $\mathbf{M}$ & 38 & 1 & $\begin{array}{l}\text { Central radiating to } \\
\text { back }\end{array}$ & 二 & + & - & - & 3 wk \\
\hline 6 & $\mathbf{M}$ & 45 & $3 \mathrm{~d}$ & Central & Constipation & + & - & - & - \\
\hline 7 & $\mathbf{M}$ & 60 & $2 \mathrm{mth}$ & Epigastric & Constipation & + & - & + & - \\
\hline 8 & $\mathbf{F}$ & 36 & 3 & Central & - & - & + & - & - \\
\hline
\end{tabular}




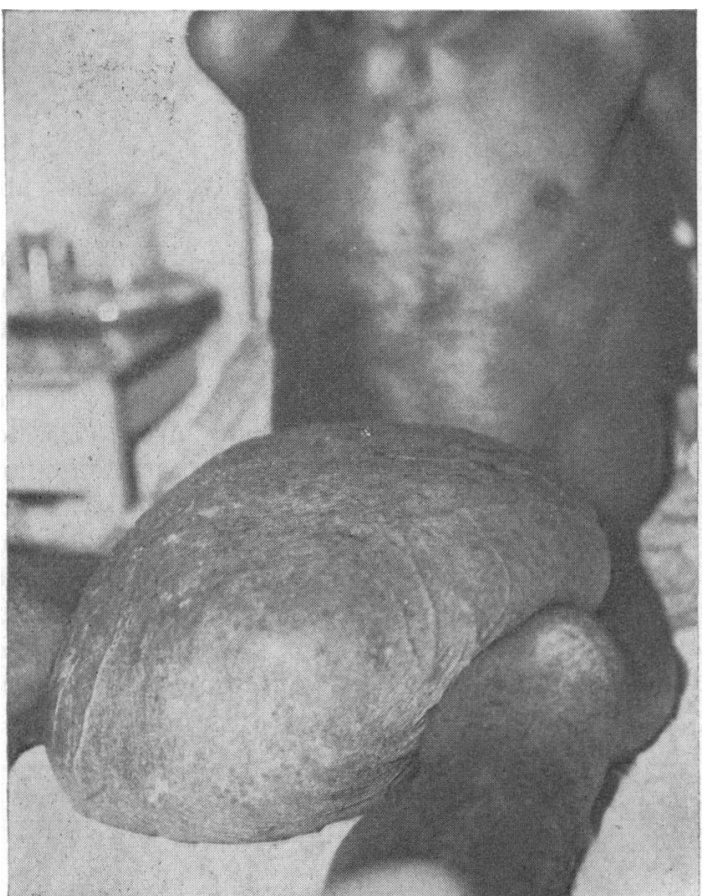

Fig. 1 Case 1. Giant inguinal hernia.

An interesting feature was the association with inguinal hernia. One patient had a giant inguinal hernia, reaching to the knee (Fig. 1). Barium meal showed a considerable length of small and large intestine in the sac with a stricture in the most dependent part (Fig. 2). Four other patients had a previous history of herniorrhaphy, three to 12 weeks

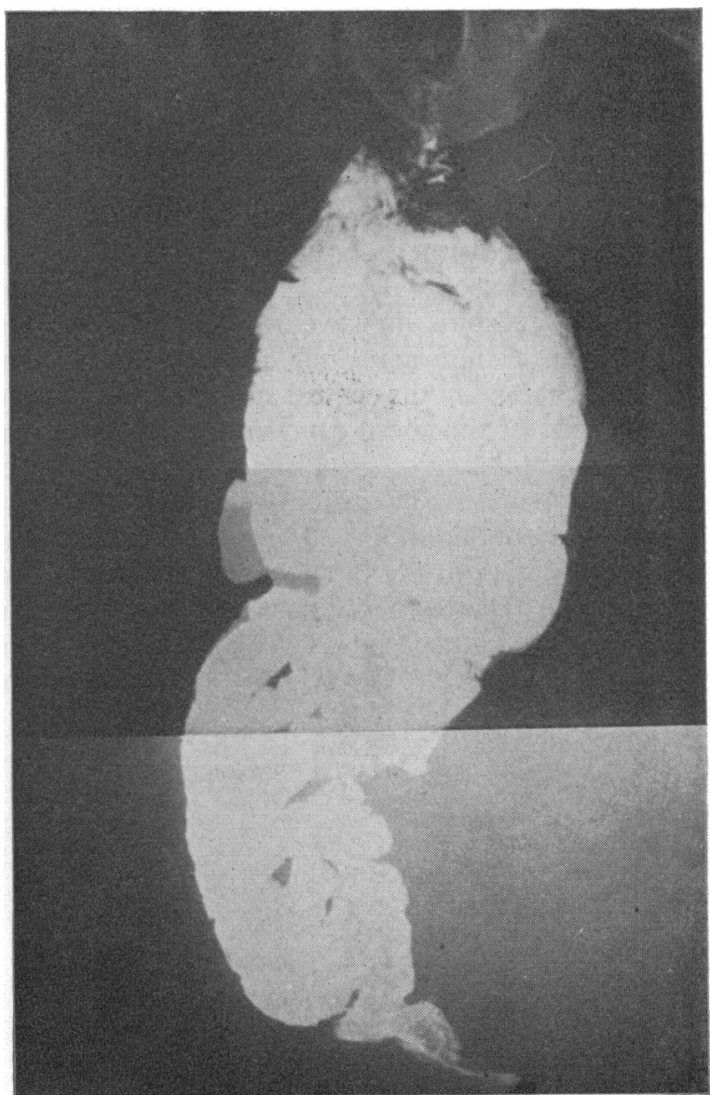

Fig. 2 Case 1. Barium meal picture. The pelvis can be made out at the upper edge. Distended loops of bowel are seen extending below this level, and a stricture is seen at the most dependent part.

Table 2 Showing pathological features of eight cases of ischaemic stricture of small intestine

\begin{tabular}{|c|c|c|c|c|c|c|c|c|c|}
\hline \multirow[t]{2}{*}{ Case no. } & \multicolumn{2}{|l|}{ Gross } & \multicolumn{6}{|l|}{ Histology } & \multirow{2}{*}{$\begin{array}{l}\text { Possible causes of } \\
\text { ischaemia }\end{array}$} \\
\hline & Site of stricture & $\begin{array}{l}\text { Mucosal } \\
\text { ulceration }\end{array}$ & $\begin{array}{l}\text { Pyloric } \\
\text { metaplasia }\end{array}$ & Siderophages & Congestion & $\begin{array}{l}\text { Damage to } \\
\text { muscularis }\end{array}$ & $\begin{array}{l}\text { Involvement } \\
\text { of serosa }\end{array}$ & $\begin{array}{l}\text { Vascular } \\
\text { changes }\end{array}$ & \\
\hline 1 & Ileocaecal region & - & - & - & + & - & + & + & Hernia \\
\hline 2 & Terminal ileum & + & + & - & + & + & + & + & Herniorrhaphy \\
\hline 3 & $\begin{array}{l}30 \mathrm{~cm} \text { proximal to } \\
\text { ileocaecal junction }\end{array}$ & + & + & - & + & + & + & + & $\begin{array}{l}\text { a. Herniorrhaphy } \\
\text { b. Atherosclerosis }\end{array}$ \\
\hline 5 & $\begin{array}{l}30 \mathrm{~cm} \text { proximal to } \\
\text { ileocaecal junction }\end{array}$ & + & - & - & + & + & + & + & $\begin{array}{l}\text { a. Herniorrhaphy } \\
\text { b. Atherosclerosis } \\
\text { c. Hypertension }\end{array}$ \\
\hline 6 & $\begin{array}{l}75 \mathrm{~cm} \text { proximal to } \\
\text { ileocaecal junction }\end{array}$ & + & - & + & + & + & + & + & $\begin{array}{l}\text { a. Atherosclerosis } \\
\text { b. Congestive } \\
\text { cardiac failure }\end{array}$ \\
\hline 7 & $\begin{array}{l}\text { Proximal jejunum } \\
\text { (4 strictures) }\end{array}$ & + & + & + & + & - & + & + & Atherosclerosis \\
\hline
\end{tabular}


before laparotomy for intestinal obstruction due to ischaemic stricture.

\section{Illustrative case history}

J. A., a 48 year old night-watchman gave a four year history of post-prandial central abdominal pain, borborygmi, alternating constipation and diarrhoea, occasional bouts of vomiting, and progressive loss of weight. A left inguinal herniorrhaphy led to some improvement, but this did not last. Because the right lung showed fibrotic infiltrative changes in the central and apical regions on radiographs of the chest, a provisional diagnosis of pulmonary tuberculosis with abdominal involvement was made. At laparotomy, a firm constrictive lesion was found about $30 \mathrm{~cm}$ proximal to the ileocaecal junction. Proximal to this the bowel was dilated. The affected loop was excised with a margin of about $12 \mathrm{~cm}$ on each side. The histology showed an ischaemic stricture. There was no evidence of

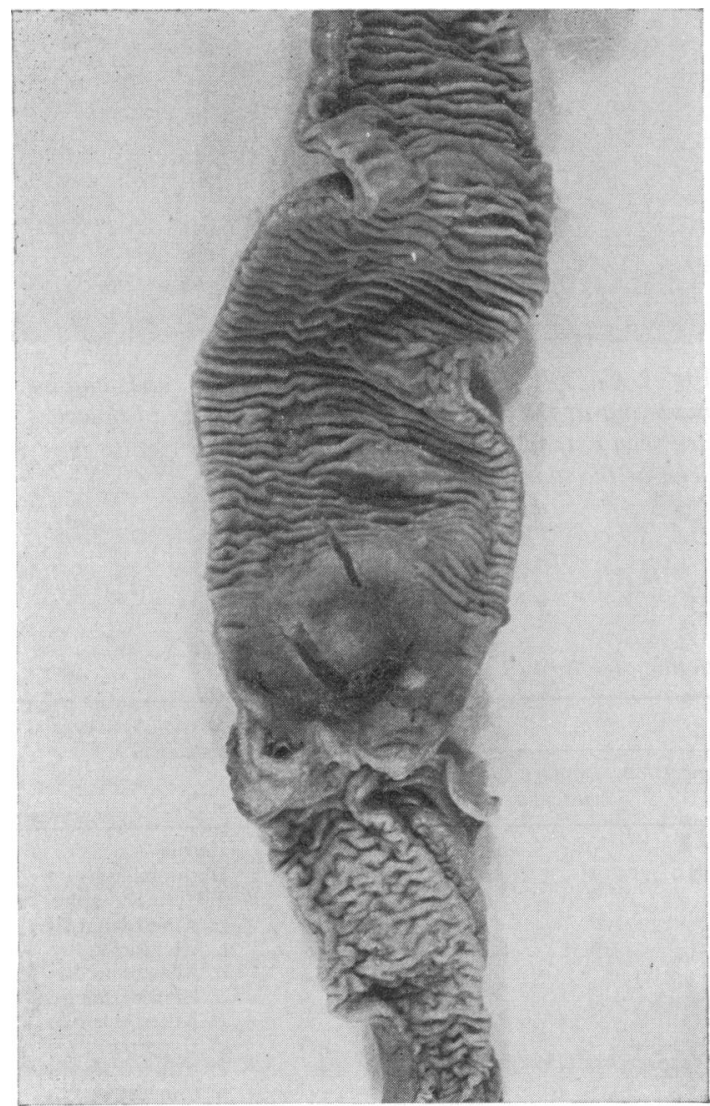

Fig. 3 Case 4. Small intestine showing a shallow ulcer crater, the edges being flush with the adjacent mucosa. The intestine is dilated above the ulcer. tuberculosis in several sections of the bowel wall and mesenteric glands.

\section{Results}

PATHOLOGICAL FEATURES

The salient gross and histological features are summarised in Table 2.

All specimens showed short areas of constriction, with varying degrees of distension of the proximal bowel. The mesentery showed thickening and fibrosis.

The mucosal surface underlying the stricture showed transverse ulcers ranging from 2.5 to $6.0 \mathrm{~cm}$ in length and involving the entire circumference. In case 7, there were four separate strictures and ulcers separated by short lengths (about $15 \mathrm{~cm}$ ) of relatively normal bowel wall. The floor of the ulcers was flush with the adjacent mucosa or showed a gentle slope with a shallow crater (Fig. 3). The floor and edges had a distinctive soft pale to dark

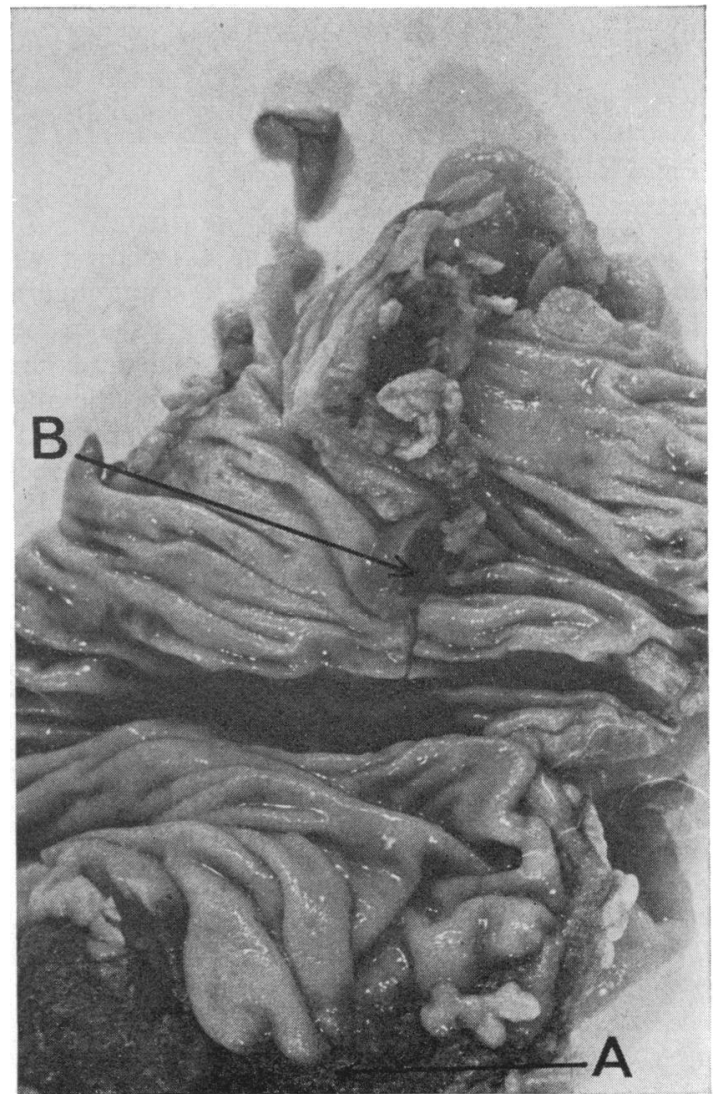

Fig. 4 Case 8. Small intestine showing an ulcer with a velvety haemorrhagic floor $(A)$, and a submucosal haematoma $(B)$ at a short distance. 


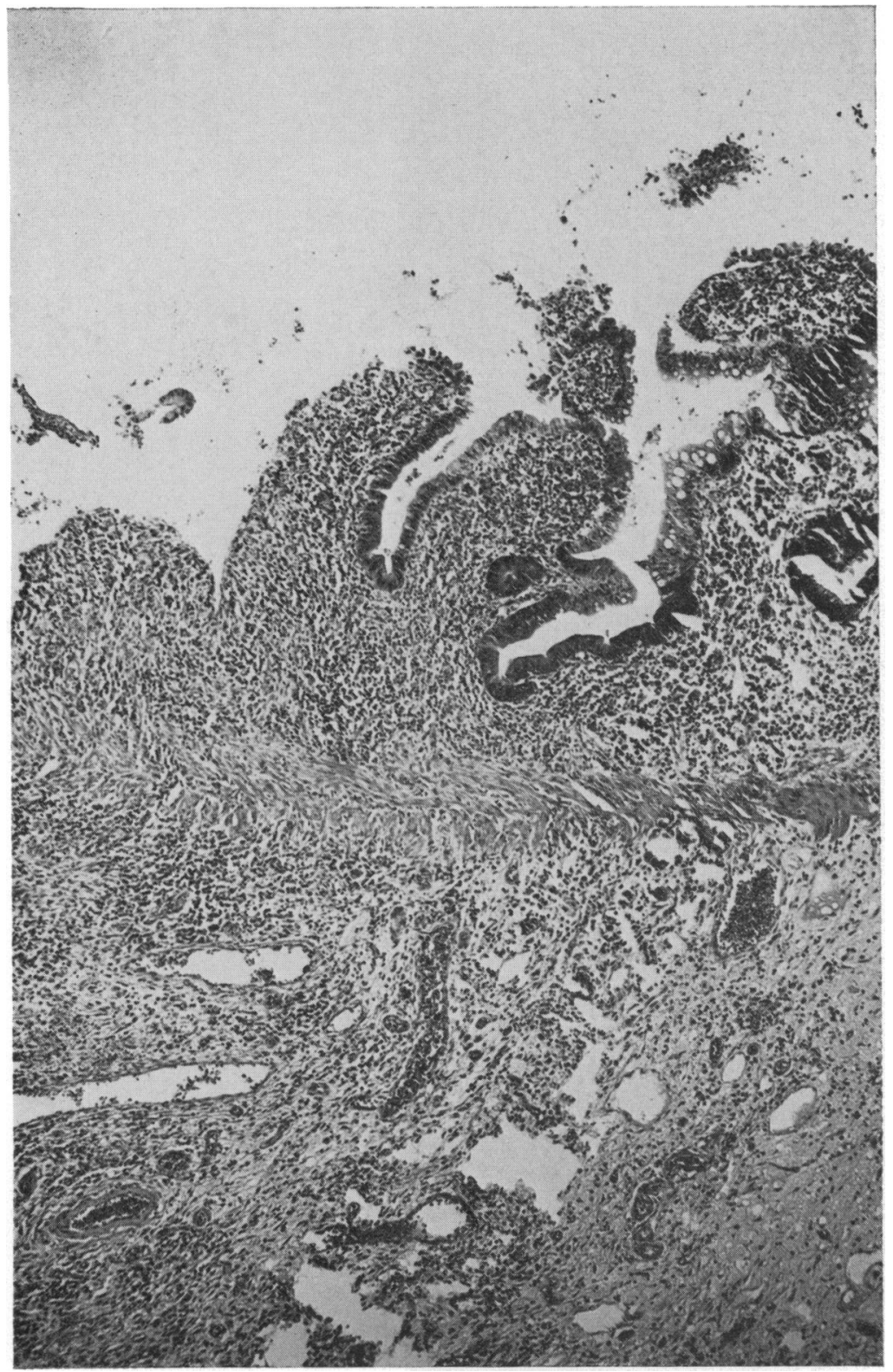

Fig. 5 Case 4. Photomicrograph, showing ulcer floor with numerous congested blood vessels.

$H$ and $E, \times 40$.

brown velvety appearance (Figs. 3, 4). In case 8, there was a small oval submucosal nodule a few centimetres from the ulcer; on sectioning, this was seen to be a small haematoma (Fig. 4).

Histologically, the ulcers showed highly vascular granulation tissue with a diffuse non-specific chronic inflammatory infiltrate, in which a number of haemosiderin-laden histiocytes were seen. The mucosa and submucosa showed severe congestion, and the inflammatory infiltrate could be seen extending through the entire thickness of the intestinal wall (Figs. 5, 6). The mucosa for some distance from the ulcer edge showed abnormalities such as loss of villous pattern, increased number of goblet cells, branching of glands, and pyloric metaplasia (Figs. 6, 7).

Blood vessel changes which could have been responsible for ischaemia were seen in the sub- 


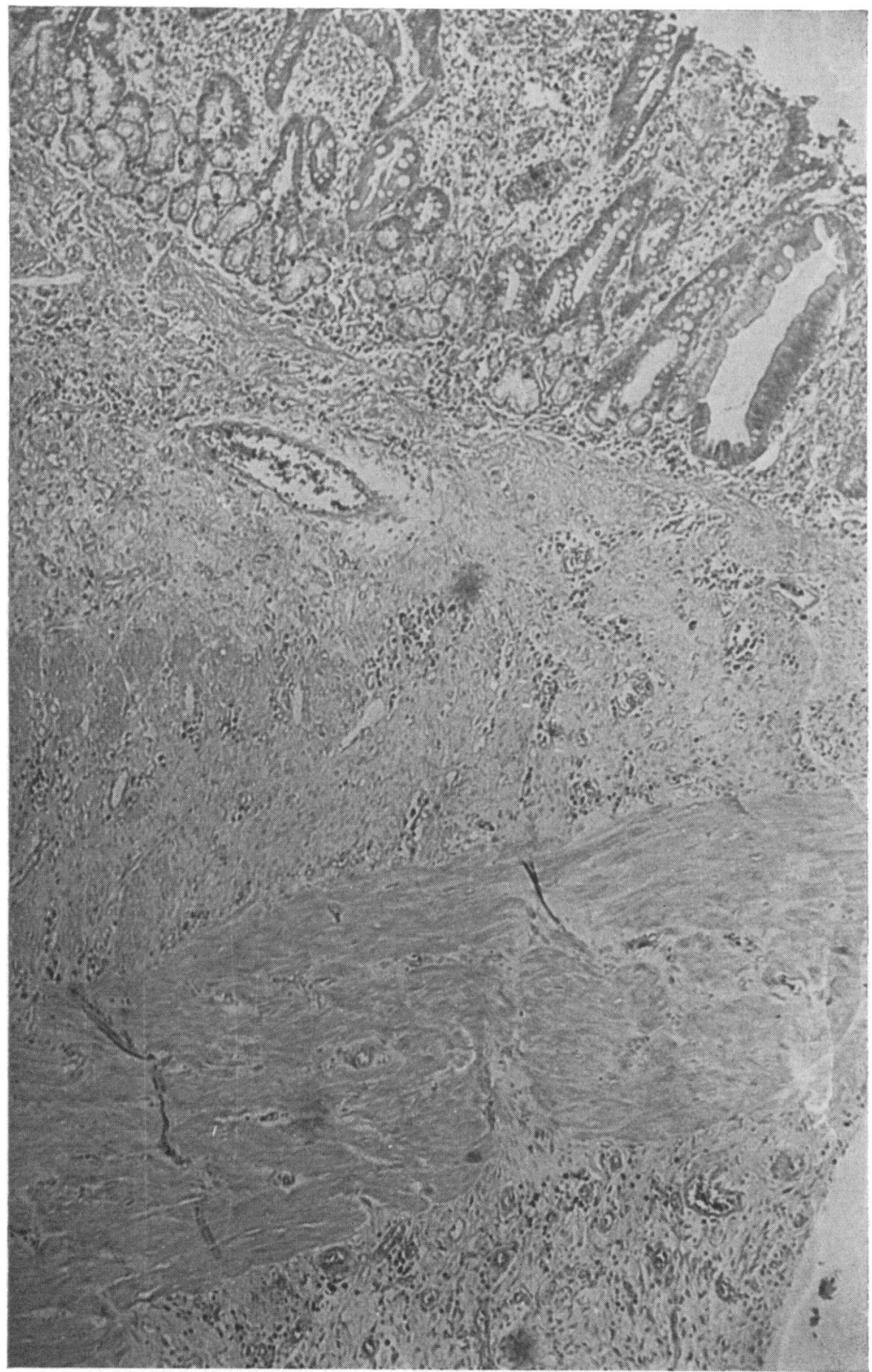

Fig. 6 Case 7. Photomicrograph of jejunum, close to edge of an ulcer, showing inflammation extending through the entire thickness of the wall. $H$ and $E$, $\times 40$.

mucosa, in the mesentery, or at both sites. Three cases showed atherosclerotic narrowing of arteries. In case 8 there was thrombotic narrowing of an artery in the mesentery, the appearances suggesting that there had been at least two episodes of thrombosis (Fig. 8). This patient was a 35 year old woman, and we could find no explanation for the thrombosis.

In the strictures related to hernia, the arterioles and venules in the submucosa appeared abnormal.
The arterioles showed intimal mucoid thickening, with focal destruction of the internal elastic lamina, while venules showed fibroelastotic thickening of the wall.

\section{Discussion}

The clinical and pathological features of acute mesenteric vascular occlusion leading to intestinal 


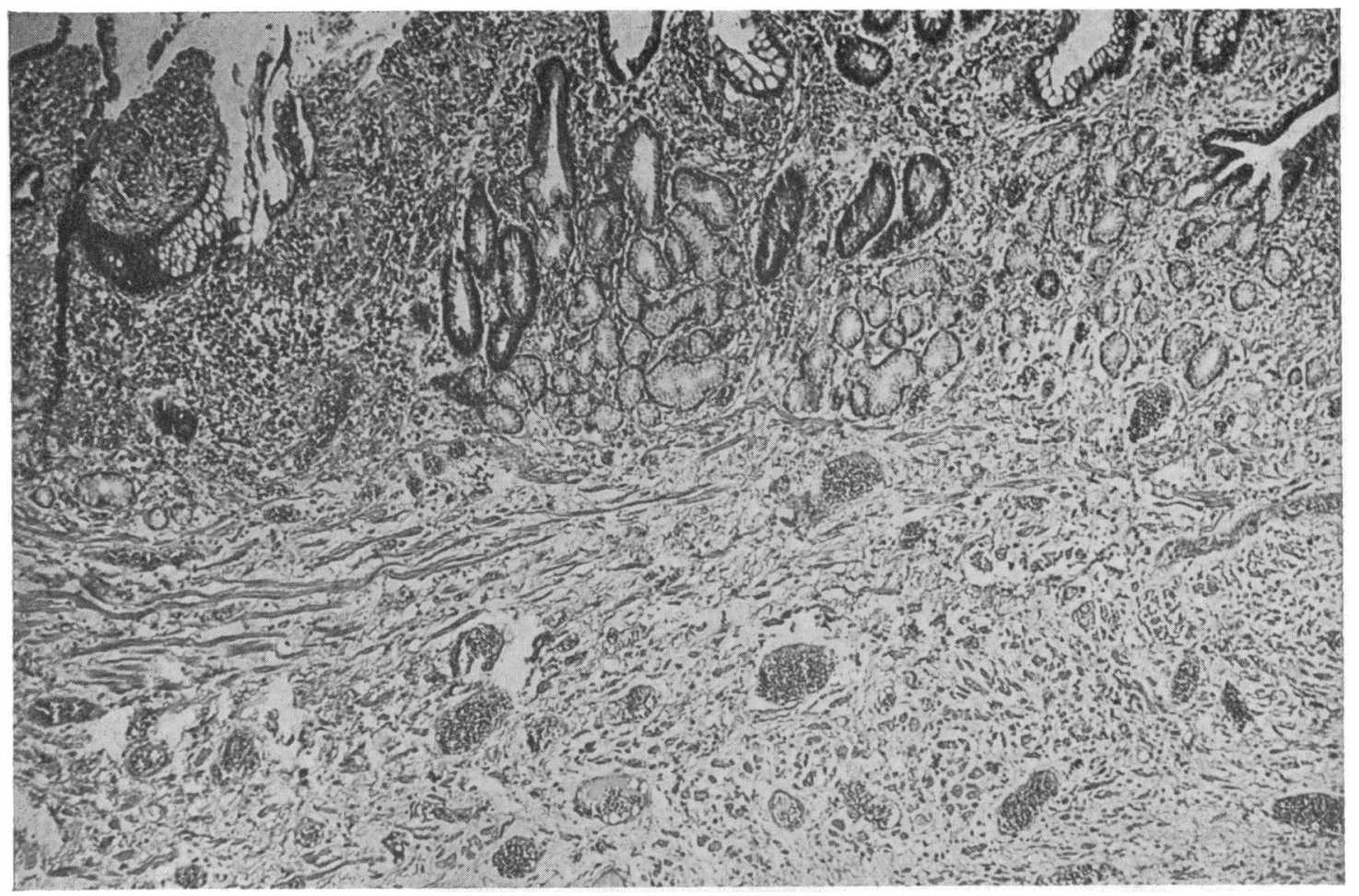

Fig. 7 Case 8. Photomicrograph of ileum close to edge of ulcer, showing distorted glands with marked pyloric metaplasia. $H$ and $E, \times 40$.

infarction are well known; this condition constitutes one of the commoner surgical emergencies. The clinical syndrome resulting from ischaemia of the gut insufficient to cause immediate infarction consists of:

1. Postprandial central or epigastric pain which may mimic the pain of peptic ulcer.

2. Alternating constipation and diarrhoea.

3. Loss of weight. This may be due to mucosal changes leading to impaired absorption, or to the 'small meal syndrome', the patient settling for small quantities of food for fear of bringing on pain (Warburg, 1905; Rob, 1970; Spiro, 1970; Ottinger, 1974).

Stricture formation can result from either slow occlusion or small vessel disease, or during the process of repair of an infarcted segment; these events can occur in intrauterine life (Spiro, 1970; deSa, 1972).

At operation, ischaemic strictures may be difficult to distinguish from Crohn's disease or tuberculosis. In our experience, the most useful diagnostic features on which to make a diagnosis of ischaemic stricture on gross examination are the presence of ulcers with the floor flush with the adjacent mucosa, the marked vascularity of the granulation tissue as shown by a haemorrhagic or velvety brown granular appearance, and the negative features of absence of cobblestoning of mucosa, tubercles on the serosal surface, and caseation in lymph nodes.

Histologically, too, it may be difficult to exclude Crohn's disease and tuberculosis. Tuberculosis can be excluded only by studying multiple sections, as granulomata may be hard to find. Whenever possible, mesenteric lymph nodes must be studied as it is well known that often they show caseous granulomata while the bowel wall may show only non-specific inflammation (Chuttani, 1970). The absence of fissuring, granulomata, and lymphoid aggregates and the presence of siderophages might be of help in differentiating ischaemic disease from Crohn's disease. Pyloric metaplasia, which was seen in four of our eight cases, was at one time considered to be highly suggestive of Crohn's disease, but has been shown to be non-specific (Lee, 1964). Transmural inflammation can also be a feature of both conditions (Morson and Dawson, 1972). Careful study of the mesentery with particular 


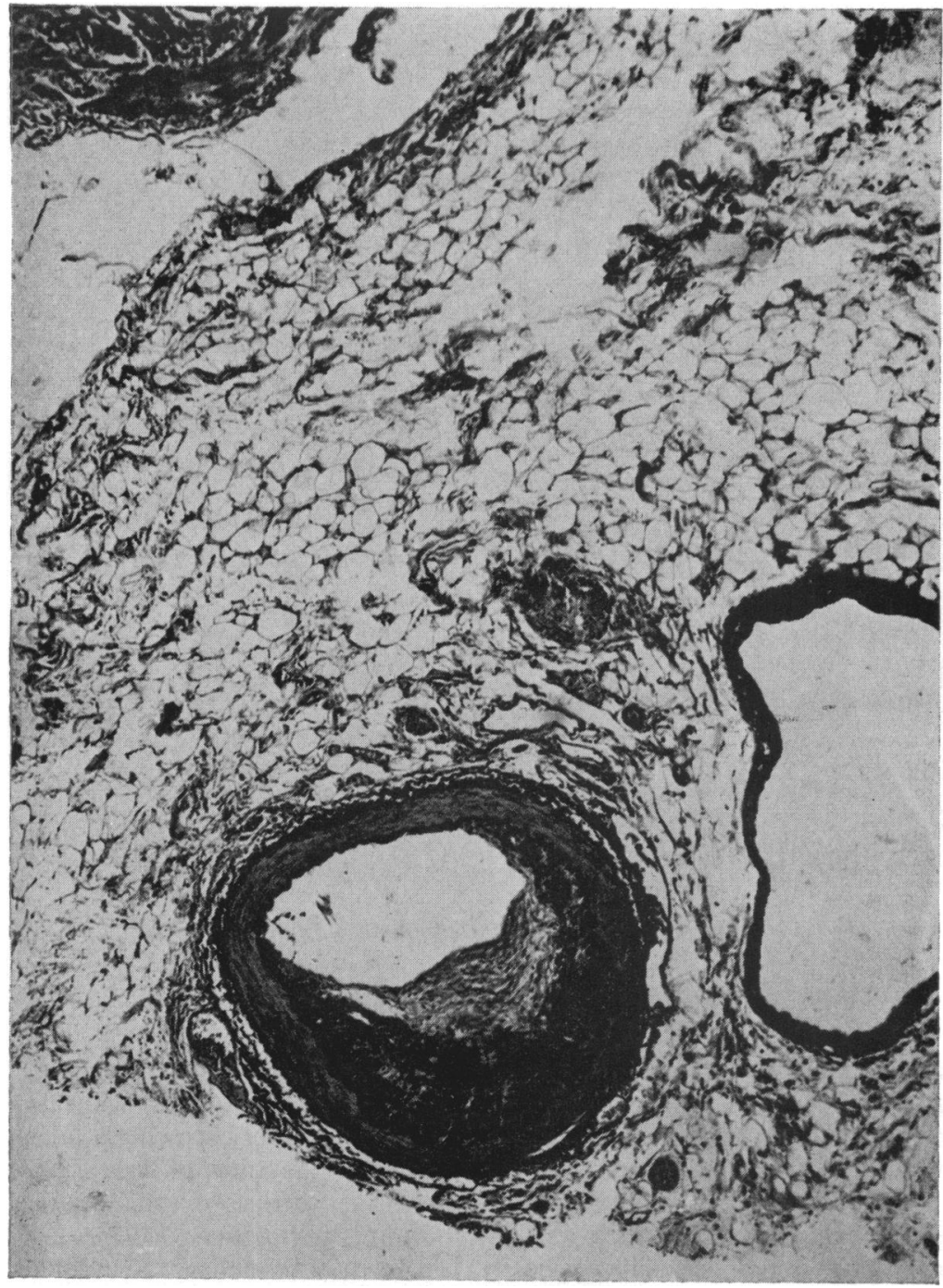

Fig. 8 Case 8. Photomicrograph of artery, showing narrowing of lumen by organising thrombus. Verhoeff-van Gieson, $\times 40$. attention to blood vessels can be of immense value; this was exemplified in our case 8 , where the intestine showed non-specific ulcerative changes. The possibility of the lesion being ischaemic in nature was suspected because the floor of the ulcer was haemorrhagic and because of the presence of a submucosal haematoma at a short distance. Multiple sections were taken through the mesentery, resulting in the detection of an artery showing partial occlusion of the lumen by thrombosis.

The points of particular interest in our series are:

a. The prevalence of ischaemic bowel strictures in Nigeria, which does not appear to have been previously reported.

b. The association of these strictures with hernia and previous inguinal herniorrhaphy. The giant inguinal hernia shown in Figs. 1 and 2 is never seen in developed countries.

c. In the four post-herniorrhaphy cases, no stricture had been seen at the first operation, and the sequence of events would suggest that the strictures developed subsequently. Small intestinal strictures after repair of hernias are considered rare, at least in developed countries (Sullivan, 1974). In developing countries like Nigeria, where roads and communication are poor, the interval between the onset of the episode of ischaemia and surgical attention may be long enough in many cases for irreversible damage to have taken place. In such circumstances, the risk of subsequent development of stricture is a strong reason to advise resection of suspicious loops of intestines whenever surgery is done for obstructed 
or strangulated hernia.

d. The region most commonly affected in superior mesenteric artery narrowing with chronic midgut ischaemia is the terminal ileum and caecum. The lesions in our post-herniorrhaphy cases involved a region of small bowel about $30 \mathrm{~cm}$ proximal to the ileocaecal junction. The probable explanation of this is that the ileocaecal junction constitutes a fixed point, so that the portion of small bowel entering a hernial sac would be at some distance from it.

We are grateful to $\mathrm{Mr} \mathrm{V} . \mathrm{O}$. N. Odiase, and $\mathrm{Mr} \mathrm{U}$. Osime for permission to report case nos. 1 and 6 respectively; to the technical staff of the Histopathology Department, University of Benin Teaching Hospital, particularly $\mathrm{Mr} \mathbf{P}$. Imarenezor and Mr J. Uwagbole; and to Mr K. Etamesor of the Medical Illustration Department, University of Benin Teaching Hospital, and to Mr P. J. Cheese, Ahmadu Bello University, Zaria, for the photography.

\section{References}

Chuttani, H. K. (1970). Intestinal tuberculosis. in Modern Trends in Gastroenterology. vol. 4, pp. 309-327. Edited by W. I. Card and B. Creamer. Butterworth: London.

deSa, D. J. (1972). Congenital stenosis and atresia of the jejunum and ileum. Journal of Clinical Pathology, 25, 1063-1070.

Lee, D. J. (1964). Pyloric metaplasia in the small intestine. Journal of Pathology and Bacteriorology, 87, 267-277.

Morson, B. C., and Dawson, I. M. P. (1972). Gastrointestinal Pathology. Blackwell: Oxford.

Ottinger, L. W. (1974). Nonocclusive mesenteric infarction. Surgical Clinics of North America, 54, 689-698.

Rob, C. H. (1970). Vascular diseases of the intestine. In Modern Trends in Gastroenterology. vol. 4, pp. 252-272. Edited by W. I. Card and B. Creamer. Butterworth: London.

Spiro, H. M. (1970). Clinical Gastroenterology, pp. 367-369. Collier-MacMillan: London.

Sullivan, J. F. (1974). Vacular disease of the intestines. Medical Clinics of North America, 58, 1473-1475.

Warburg, E. (1905). Ueber Dyspragia intermittens Angiosclerotica Intestinalis. Münchener medizinische Wochenschrift, 52, 1174-1176. (Cited by Rob, C. H. 1970). 